\title{
PENGELOLAAN DANA INFAK PERSPEKTIF MANAJEMEN DAN HUKUM ISLAM
}

\author{
Julianti, Nur Taufik Sanusi \\ Universitas Islam Negeri Alauddin Makassar \\ Email: Jhuli941@gmail.com
}

\begin{abstract}
Abstrak
Allah swt. menurunkan agama Islam ke dunia sebagai rahmat bagi alam semesta. Agama Islam mendambakan kedamaian dan kesejahteraan bagi seluruh umat manusia. Islam memberikan tuntunan bagi tata hidup dan kehidupan manusia, baik yang berkenaan dengan hubungan manusia dengan Allah maupun hubungan manusia dengan manusia. Dalam pengentasan kemiskinan dengan dana infak adalah salah satu alternatif untuk mengurangi masyarakat yang kurang mampu dan sangat membantu untuk pembangunan masjid, masjid memiliki fungsi bukan hanya sekedar beribadah semata tetapi sebagai wadah untuk belajar ilmu agama dan dakwah. Pokok permasalahan yang menjadi kajian dalam penelitian ini yaitu pengelolaan dana infak perspektif manajemen dan hukum Islam studi kasus Masjid Agung Nujumul Ittihad Sinjai. Jenis penelitian yang digunakan dalam penelitian ini adalah jenis penelitian lapangan. Untuk pengumpulan datanya menggunakan metode pengumpulan data melalui observasi, wawancara, dan dokumentasi. Adapun pendekatan yang digunakan ada dua yaitu: pendekatan normatif (syar'i), yuridis dan pendekatan empiris. Hasil penelitian menunjukkan bahwa (1) tata kelola Masjid Agung Nujumul Ittihad sinjai memperoleh anggaran dana operasional dari jamaah yang tidak bersifat mengikat jumlah maupun waktunya, (2) konsep pengelolaan dana infak perspektif manajemen dapat disimpulkan bahwa pengelolaan dana infak di Masjid Agung Nujumul Ittihad sesuai dengan hukum Islam dengan memberikan infak kepada orang yang membutuhkan.
\end{abstract}

\section{Kata Kunci: Dana Infak, Hukum Islam, Masjid}

\begin{abstract}
Allah swt sent Islam to the world as a mercy for the universe. Islam desires peace and prosperity for all mankind. Islam provides guidance for the way of life and human life, both with regard to human relations with God and human relations with humans. In alleviating poverty with infaq funds, it is an alternative to reduce the underprivileged and is very helpful for the construction of mosques, mosques have a function not only for worship but as a forum for learning religious knowledge and da'wah. The main problem that is studied in this research is the management of infaq funds from a management perspective and Islamic law, the case study of the Great Mosque of Nujumul Ittihad Sinjai. The type of research used in this study is a type of field research. For data collection using data collection methods through observation, interviews, and documentation. There are two approaches used, namely: normative (syar'i)) approach, juridical and empirical approach. The results showed that (1) the management of the Great Mosque of Nujumul Ittihad Sinjai obtained an operational fund budget from the congregation which was not binding on the amount and time, (2) the concept of infak fund management from a management perspective, it can be concluded that the management of infaq funds at the
\end{abstract}


Great Mosque of Nujumul Ittihad is in accordance with Islamic law by giving infaq to people in need.

Keywords: Infaq Fund, Islamic Law, Mosque

\section{A. PENDAHULUAN}

Allah swt menurunkan agama Islam ke dunia sebagai rahmat bagi alam semesta. Agama Islam mendambakan kedamaian dan kesejahteraan bagi seluruh umat manusia. Islam memberikan tuntunan bagi tata hidup dan kehidupan manusia, baik yang berkenaan dengan hubungan manusia dengan Allah maupun hubungan manusia dengan manusia. Salah satu sendi pokok ajaran agama Islam adalah zakat, infaq dan sedekah, disamping shalat, puasa, dan haji. Islam adalah agama yang diturunkan Allah swt. Kepada umat manusia untuk menuntun kehidupan mereka menuju kebahagiaan, baik di dunia maupun di akhirat

Masjid berasal dari Bahasa arab sajada yang berarti tempat sujud atau tempat menyembah Allah swt. Bumi yang kita tempati ini adalah masjid bagi kaum muslimin. Setiap muslim boleh melakukan shalat di wilayah manapun di bumi ini; terkecuali di atas kuburan, di tempat yang bernajis, dan di tempat-tempat yang menurut ukuran syariat Islam tidak sesuai untuk dijadikan tempat shalat. Dijelaskan dalam QS. At-Taubah/9:18

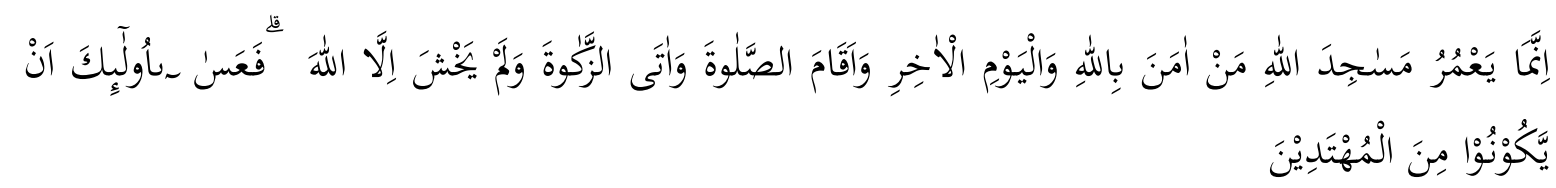

Terjemahnya:

"Sesungguhnya yang (pantas) memakmurkan masjid-masjid Allah hanyalah orangorang yang beriman kepada Allah dan hari akhir, serta mendirikan shalat, menunaikan zakat, tidak takut (kepada siapapun) selain Allah. Maka mudah-mudahan mereka termasuk orang-orang yang mendapat petunjuk."

Masjid tidak bisa dilepaskan dari masalah sholat. Berdasarkan sabda nabi di atas setiap orang bisa melakukan sholat dimana saja, di rumah, di jalan, dan tempat lainnya. Selain itu masjid merupakan tempat orang berkumpul dan melakukan shalat secara berjamaah, dengan tujuan meningkatkan solidaritas dan silaturahmi di kalangan kaum muslimin. Di masjid pulalah tempat terbaik untuk melangsungkan shalat jumat.

Di masa Nabi saw. Ataupun di masa sesudahnya. Masjid menjadi pusat atau sentral kegiatan kaum muslimin. Kegiatan di bidang pemerintahan pun mencakup, ideologi, politik, ekonomi, sosial, peradilan, dan kemiliteran dibahas dan dipecahkan di lembaga masjid. Masjid berfungsi pula sebagai pusat pengembangan kebudayaan Islam, terutama saat gedung-gedung khusus untuk itu belum didirikan. Masjid juga merupakan ajang halaqah atau diskusi, tempat mengaji, dan memperdalam ilmu-ilmu pengetahuan agama maupun umum. ${ }^{2}$ Tujuan umum syariat dalam menetapkan hukum ialah menegakkan kemaslahatan manusia di dalam kehidupan, menarik manfaat dan menolak kemudharatan.

\footnotetext{
${ }^{1}$ Kementerian Agama. RI, al-Qur'an dan Terjemahnya ( Jakarta: Jatinegara, 2012), h.189.

2Mohammad E, dkk" Manajemen Masjid" (Jakarta: Gema Insani Press, 1996), h. 21.
} 
Tidak ada satu hukum dalam Islam yang tidak mengandung kemaslahatan hakiki baik itu di dunia maupun di akhirat, disinilah keistimewaan hukum syariat dalam Islam. ${ }^{3}$

Kemiskinan merupakan masalah yang tengah dihadapi oleh seluruh bangsa yang ada di dunia, termasuk Indonesia. Salah satu upaya yang dilakukan untuk mengatasi masalah kemiskinan tersebut adalah melakukan pemberdayaan ekonomi bagi masyarakat miskin. Mengingat bahwa mayoritas penduduk Indonesia adalah muslim, maka peluang untuk melakukan upaya pengetesan kemiskinan dengan menggunakan zakat, infaq, dan sedekah terbuka lebar. Dalam menghadapi kenyataan adanya fenomena kemiskinan, Islam memiliki suatu konsep, dan dengan konsep itu dapat membantu meringankan beban kemiskinan. Dalam sistem kemasyarakatan Islam, seseorang tidak boleh dibiarkan menjadi kelaparan, tanpa pakaian, hidupnya menggelandang, tidak memiliki tempat tinggal atau kehilangan kesempatan untuk membina keluarganya. ${ }^{4}$

Hukum Islam sebagai tatanan hukum yang dipegang (ditaati) oleh mayoritas penduduk dan rakyat Indonesia adalah hukum yang telah hidup di dalam masyarakat yang merupakan sebagian dari ajaran dan keyakinan Islam dan ada dalam kehidupan hukum nasional serta merupakan bahan dalam pembinaan dan pengembangannya. Dari sumber ajarannya, realitas kehidupan hukum masyarakat, sejarah pertumbuhannya, dan perkembangan hukum di Indonesia, terlihat beberapa teori yang sudah mantap dan dalam pertumbuhan. Teori-teori tentang berlakunya hukum Islam di Indonesia tergambarkan dalam enam teori, yaitu:

1. Ajaran Islam tentang penaatan hukum. Hal ini dapat dilihat dalam al-Qur'an surah al-Baqarah ayat 5 .

2. Teori penerimaan autoritas hukum, H.A.R. gibb dalam bukunya The Modern Trends of Islam mengatakan bahwa jika orang Islam telah menerima Islam sebagai agamanya, maka ia menerima autoritas hukum Islam terhadap dirinya.

3. Teori receptie in complexu, teori yang mengatakan bahwa hukum yang berlaku bagi rakyat pribumi adalah hukum agamanya.

4. Teori receptie, teori ini menyatakan bahwa hukum yang berlaku bagi rakyat jajahan (pribumi) adalah hukum adat. Hukum islam menjadi hukum kalua telah diterima oleh masyarakat sebagai hukum adat. Teori ini muncul karena keperluan penjajah yang di populerkan oleh Cristian Snouck Hurgronye, kemudian didukung dan dikembangkan oleh Van Vollenhoven dan Ter Haar.

5. Teori receptie exit, maksudnya adalah bahwa teori receptie harus keluar dari teori hukum nasional Indonesia karena bertentangan dengan UUD 1945 serta bertentangan dengan al-Qur'an dan sunnah rasul.

6. Teori receptie a contrario teori ini menyatakan bahwa hukum yang berlaku bagi rakyat adalah hukum agamanya, hukum adat baru berlaku kalau tidak bertentangan dengan hukum agama.

Dalam permasalahan ini mengingat pokok masalah mengenai pengelolaan dana infaq perspektif manajemen dan hukum Islam mengamati bahwa apakah konsep pengelolaan dana infaknya terstruktur dengan baik pengelolaannya atau juga di infaqkan dengan orang yang kurang mampu. Dalam pengentasan kemiskinan dengan dana infaq adalah salah satu alternatif untuk mengurangi masyarakat yang kurang mampu dan sangat membantu untuk

\footnotetext{
${ }^{3}$ Musyfikah Ilyas "Memaknai Fashion dalam Hukum Islam” al-Daulah: Jurnal Hukum Tata Negara Fakultas Syariah dan Hukum, vol.5, no.1, (Juni 2016), h. 140.

${ }^{4}$ Andi M Fadly Taher. dkk "Sistem Pengelolaan Dana Kotak Infaq dan Sedekah Keliling Masjid di Pasar 45 Manado, Jurnal Ilmiah al-Syir'ah. Vol.14 No.2, (2016), h. 54.
} 
pembangunan masjid tersebut. Masjid memiliki fungsi bukan hanya sekedar beribadah semata tetapi sebagai wadah untuk belajar ilmu agama dan dakwah.

Kegiatan- kegiatan masjid tersebut mendapatkan sumber dana yang berasal dari masyarakat antara lain, dari zakat, infak, wakaf, donatur, sumbangan dari pemerintah, sumbangan dari instansi swasta, dan lain sebagainya. Sumber dana tersebut harus di kelola masjid untuk kesejahteraan masjid dan jamaah. Namun dalam pemanfaatan dana masjid tersebut seringkali tidak efektif, dikarenakan sebagian besar dana yang dimiliki masjid hanya diorientasikan untuk kegiatan operasional masjid, pembangunan fisik serta pemeliharaannya.

Dana infak masjid biasanya di dapat melalui kotak amal yang ada di masjid, Kotak infak jumat, dan dana dari donatur masjid. Masjid ber Infak adalah perintah Allah swt. sebagaimana dalam firman pada QS. al-Hadid/57:7

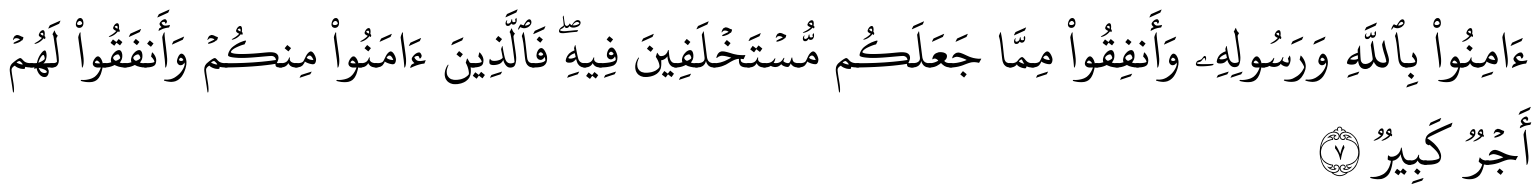

Terjemahnya:

"Berimanlah kamu kepada Allah dan Rasul-Nya dan infakkanlah (dijalan Allah) sebagian dari harta yang dia telah menjadikan kamu sebagai penguasanya (amanah). Maka orang-orang yang beriman diantara kamu dan menginfaqkan (hartanya di jalan Allah) memperoleh pahala yang besar". 5

Ayat tersebut menjelaskan perintah untuk beriman kepada Allah swt dan rasul-Nya serta perintah untuk berinfak dijalan Allah swt. dan di dalam sebagian harta yang telah diberikan Allah swt. telah menjadikan manusia sebagai penguasanya, untuk diberikan kepada orang yang berhak. Karena harta setiap manusia terdapat bagian Allah swt. bagi mereka yang membutuhkan. Harta yang dimiliki manusia hanya titipan Allah swt. Pendayagunaan dana infak dalam rangka untuk peningkatan kesejahteraan umat, seperti pembelian alat-alat produksi, disumbangkan untuk masyarakat yang kurang mampu dan sejenisnya. Pembiayaan ini adalah bentuk kepedulian kepada para duafa atau pengangguran agar dapat berdaya. Keberadaan masjid diharapkan mampu menjadi Lembaga yang mampu menghimpun dana zakat, infak, sedekah, maupun wakaf, dan mengelola secara produktif. Sehingga hasilnya dapat dialokasikan sebagai dana infak produktif untuk membantu pemberdayaan ekonomi masyarakat.

Dana infak yang terkumpul bisa saja dialokasikan di pembangunan masjid atau diberikan kepada masyarakat yang perekonomiannya dibawah garis kemiskinan. Merujuk pada dalil al-Qur'an (QS. al-Baqarah/2:195)

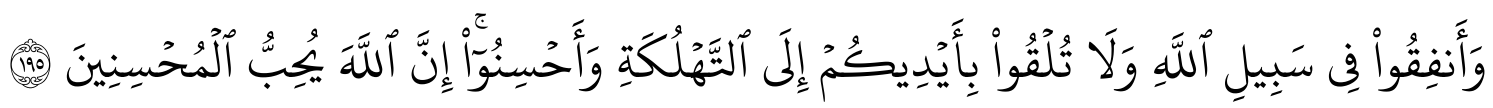

\footnotetext{
${ }^{5}$ Kementerian Agama. RI, al-Qur'an dan Terjemahnya, h.539.
} 
Terjemahnya:

"Infakkanlah (hartamu) dijalan Allah, dan janganlah kamu jatuhkan (diri sendiri) ke dalam kebinasaan dengan tangan sendiri, dan berbuat baiklah. Sesungguhnya Allah menyukai orang-orang yang berbuat baik". ${ }^{6}$

Bukan hanya diperuntukkan untuk masjid saja, tetapi juga untuk kesejahteraan masyarakat pula sehingga perekonomian masyarakat sekitar masjid akan lebih baik. Meskipun asumsi pengelolaan mengenai potensi dana infak perspektif manajemen dan hukum Islam maka penyusun membutuhkan penelitian yang lebih lanjut, maka peneliti ingin melakukan penelitian mengenai "Pengelolaan Dana Infak Perspektif Manajemen dan Hukum Islam (Studi Kasus Masjid Agung Nujumul Ittihad Sinjai Kab. Sinjai), untuk dapat mengetahui proses pengelolaan dana infak perspektif manajemen dan hukum Islam masjid Agung nujumul ittihad sinjai.

\section{B. METODE PENELITIAN}

Jenis Penelitian yang digunakan dalam penelitian ini adalah jenis kualitatif lapangan. Adapun pendekatan yang digunakan ada dua yaitu: pendekatan normatif (syar' $i$ ), yuridis dan pendekatan empiris. Kemudian sumber data primer yaitu wawancara yang dilakukan di Masjid Agung Nujumul Ittihad Sinjai Utara, dan sumber data sekunder yaitu bersumber dari kepustakaan (library research). Metode pengumpulan data yang dilakukan yaitu metode observasi, wawancara, dan dokumentasi.

\section{HASIL DAN PEMBAHASAN}

\section{Tata Kelola Masjid Agung Nujumul Ittihad Sinjai}

Masjid Agung Nujumul Ittihad adalah masjid yang mempunyai tata kelola manajemen yang memperoleh anggaran dana operasional dari jamaah yang tidak bersifat mengikat jumlah maupun waktunya. Anggaran dana operasional diperoleh tidak hanya dari masyarakat setempat tetapi juga masyarakat yang melintas dari daerah lain berinfak. Masjid Agung Nujumul Ittihad setiap malam senin, rabu, kamis, dan minggu melakukan kajian rutin. Masjid Agung Nujumul Ittihad memiliki visi dan misi. ${ }^{7}$ Adapun tujuan Masjid Nujumul Ittihad Sinjai Utara adalah:

1. Terwujudnya umat Islam yang mengamalkan ajaran-ajaran Islam, taat beribadah dan selalu memakmurkan masjid

2. Terwujudnya tempat untuk masyarakat dalam melakukan kegiatan mengajar di masjid agung sinjai

3. Terwujudnya kenyamanan dalam beribadah

Masjid Agung Nujumul Ittihad menyediakan tempat bagi masyarakat atau anggota pengurus masjid yang ingin berjualan di sekitar area masjid untuk kesejahteraan umat, di mana di satu sisi untuk menjadi salah satu sumber dana infak dan disisi lain membantu perekonomian umat Islam. Salah satu yang telah berdiri di Masjid Agung Nujumul Ittihad yaitu UKM Usaha mikro pemberdayaan ekonomi yang didirikan oleh remaja Masjid Agung Nujumul Ittihad, dimana menjadi salah satu sumber dana infak. Berikut visi dan misi dari Masjid Agung Nujumul Ittihad, diantaranya:

\footnotetext{
${ }^{6}$ Kementerian Agama RI, al-Qur'an dan Terjemahnya, h.31.

${ }^{7}$ Muhal Arsyad, Dana Dan Keuangan Masjid Nujumul Ittihad Sinjai, Wawancara, Sinjai 22 Februari 2021.
} 


\section{Visi:}

1) Mewujudkan seluruh warga masyarakat khususnya warga sinjai yang beriman dan bertakwa, menjunjung tinggi nilai-nilai agama, memiliki kepedulian antar sesama umat beragama.

Misi:

1) Menjalin Ukhuwah Islamiah dan Ukhuwah Wathoniyah dengan sesama warga, sesama masjid, masyarakat sekitar, lembaga-lembaga lain yang bernuansa Islam.

2) Meningkatkan kualitas keimanan dan ketakwaan jamaah agar masjid menjadi makmur antara lain melalui kultum, ceramah agama, dan pengajian.

3) Melaksanakan sistem pembukuan dan pelaporan secara transparan.

4) Menjaga Kebersihan dan memberikan kenyamanan kepada jamaah baik masyarakat sinjai maupun masyarakat yang melintas daerah yang melaksanakan shalat di masjid agung sinjai utara.

5) Membesarkan dan menghidupkan syiar Islam setiap hari dan pada hari acara keIslaman.

6) Mengumpulkan dan menyalurkan zakat, infak, dan sedekah

Dalam melakukan tata kelola masjid di lakukan tiga program kerja seperti kegiatan peribadatan, Pendidikan, dan kegiatan renovasi, diantaranya sebagai berikut:

1. Kegiatan peribadatan dilakukan dengan maksud tujuan membuat jadwal Imam dan muadzin shalat lima waktu, membuat jadwal khatib jumat dan bilal, membuat jadwal piket marbot, dan mengadakan kajian rutin yang di lakukan di malam hari yang telah ditentukan.

2. Kegiatan Pendidikan dilakukan dengan maksud tujuan meneruskan kegiatan taklim (harian dan mingguan), mengadakan Pendidikan al-Qur'an dan keIslaman untuk anak-anak, dan remaja tanpa biaya.

3. Kegiatan renovasi dilakukan dengan maksud tujuan membersihkan toilet dan tempat wudhu yang baru sesuai dengan tuntunan syariat Islam, merapikan eksterior masjid dan mengadakan kegiatan masjid bersih dengan mengikutsertakan peran jamaah.

Adapun tujuan Masjid Nujumul Ittihad Sinjai Utara adalah:

1. Terwujudnya umat Islam yang mengamalkan ajaran-ajaran Islam, taat beribadah dan selalu memakmurkan masjid

2. Terwujudnya tempat untuk masyarakat dalam melakukan kegiatan mengajar di masjid agung sinjai

3. Terwujudnya kenyamanan dalam beribadah.

\section{Konsep Pengelolaan Dana Infak Perspektif Manajemen Dan Hukum Islam}

Menurut kompilasi Hukum Ekonomi Syariah infaq adalah pendermaan atau pemberian rezeki/karunia atau penafkahan sesuatu kepada pihak lain, berdasarkan rasa ikhlas dengan tujuan untuk mendapatkan ridha Allah. ${ }^{8}$ Dapat diketahui bahwa infak adalah salah satu bentuk keadilan dalam mendistribusikan kekayaan, dimana dalam Islam tujuan dari distribusi kekayaan adalah agar kekayaan tidak menumpuk pada segolongan kecil masyarakat. Karena dalam harta itu ada hak-hak orang miskin.

\footnotetext{
${ }^{8}$ Kompilasi Hukum Ekonomi Syariah, (Jakarta: Kencana Prenada Media Group, 2008), h. 205.
} 
Dana infak berasal dari masyarakat, pengurus masjid dan donasi dari pemerintah setempat yang digunakan untuk pembangunan masjid Konsep pengelolaan dana infak di Masjid Agung Nujumul Ittihad digunakan untuk operasional masjid. Pertama upah cleaning service, yang melakukan pembersihan masjid setiap hari dan upah petugas imam masjid. Kedua, operator listrik atau sound system. Ketiga, operasional ibadah yang dilakukan setiap malam senin, rabu, kamis dan malam minggu yaitu kajian rutin yang tentunya mengeluarkan dana intensif dan setiap khatib jum'at dana intensif juga dikeluarkan. Keempat, operasional perawatan masjid seperti dilakukannya rehabilitas tempat wudhu juga merupakan salah satu alur pendistribusian dana infak yang diperoleh masjid yang dipergunakan untuk perawatan dan renovasi masjid bila ada kerusakan. Pengecatan dan perawatan lampu yang dilakukan 6 bulan sekali juga mengeluarkan biaya. Semua biaya yang digunakan untuk dana operasional diatas berasal dari dana infak. ${ }^{9}$

Masjid Agung Nujumul Ittihad menyediakan tempat bagi masyarakat atau anggota pengurus masjid yang ingin berjualan di sekitar area masjid untuk kesejahteraan umat, di mana di satu sisi untuk menjadi salah satu sumber dana infak dan disisi lain membantu perekonomian umat Islam, dana infak juga diperuntukkan bagi umatnya. Sebagaimana firman Allah swt dalam QS al-Ma'arij/70:24-25

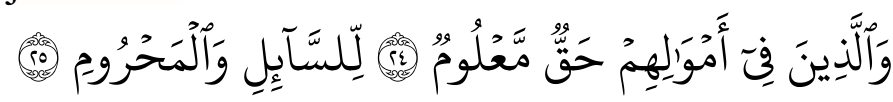

Terjemahnya:

Dan orang- orang yang dalam hartanya disiapkan bagian tertentu, bagi orang (miskin) yang meminta dan yang tidak meminta. ${ }^{10}$

Salah satu yang telah berdiri di masjid agung nujumul ittihad yaitu UKM Usaha mikro pemberdayaan ekonomi yang didirikan oleh remaja masjid Agung Nujumul Ittihad, dimana menjadi salah satu sumber dana infak. Dana infak yang diberikan tidak ditentukan oleh masjid. Infak diberikan setiap bulan wajib yang tidak diketahui jumlahnya, melainkan memberi infak seikhlasnya atau sukarela tergantung kemampuan, ada kemungkinan jika UKM tersebut mendapat keuntungan yang lebih besar maka lebih besar pula infak yang diberikan begitupun sebaliknya ketika keuntungan yang didapatkan tidak seperti biasanya yang diinfakkan mungkin sedikit berbeda ketika mendapat keuntungan yang lebih besar. Masjid Agung Nujumul Ittihad tidak memberikan patokan infak kepada usaha UKM karena tidak selamanya yang namanya usaha ada untung dan rugi. ${ }^{11}$ Masjid Agung Nujumul Ittihad ikut serta dalam membantu umat muslim yang terkena musibah bencana alam seperti yang baru ini terjadi gempa donggala, palu, masamba dan palestina. Masjid Agung Nujumul Ittihad ikut mengulurkan bantuan dengan memberi sejumlah dana yang dapat digunakan oleh umat muslim yang terkena bencana yang berasal dari dana infak masjid, dana infak yang dikeluarkan seperti itu masuk dalam kategori dana infak yang tidak terduga. Selain itu Masjid Agung Nujumul Ittihad berperan sebagai media penyalur

${ }^{9}$ Muh Ramlan Hamid, Ketua Umum Masjid Nujumul Ittihad Sinjai, Wawancara, Sinjai 26 Februari 2021.

${ }^{10}$ Kementerian Agama RI, al-Qur'an dan Terjemahnya, h. 570.

${ }^{11}$ Kamaruddin, Petanaman Dan Keindahan Masjid Nujumul Ittihad Sinjai, Wawancara, Sinjai 26 Februari 2021. 
bantuan dari masyarakat yang ingin ikut memberikan bantuan berupa dana infak dan berupa makanan maupun pakaian. ${ }^{2}$

Adapun Pengelolaan dana infak masjid tidak hanya digunakan untuk operasional masjid tetapi juga disalurkan kepada masyarakat yang berhak menerima infak, di mana pengelolaan dana infak masjid itu sendiri dilakukan guna untuk membantu orang lain atau masyarakat yang membutuhkan dan fakir miskin dari kotak amal masjid yang dana infaknya berasal dari masyarakat setempat dan masyarakat yang melintas daerah yang singgah di masjid sholat dan berinfak yang tidak diketahui jumlah dan waktunya. Kemudian disalurkan kepada masyarakat atau yang berhak menerima sesuai aturan yang ditetapkan oleh agama Islam yang berhak menerimanya, dan juga infak masjid disalurkan di hari jumat berkah bersama jamaah lainnya. ${ }^{13}$

Adapun laporan keuangan infak Masjid Agung Nujumul Ittihad keseluruhan pada bulan januari yang diumumkan setiap hari jumat dimulai pada tanggal 29 Januari totalnya sebesar Rp. 40.836.105. Pada bulan Februari tercatat mulai tgl 5 sebesar Rp. 9.235.000, tgl 12 sebesar Rp. 9.720.000, tgl 19 sebesar Rp. 8.481.000. Pada bulan Maret pada tanggal 5 tercatat sebesar Rp. 10.603.000, tgl 12 sebesar Rp. 8.047.000, tgl 19 sebesar Rp. 8.939.500, tgl 26 sebesar Rp. 8.270.000. Pada bulan April pada tanggal 2 tercatat sebesar Rp. 10. 218.000, tgl 9 sebesar Rp. 7.728.500, tgl 16 sebesar Rp. 10.126.000, tgl sebesar 23 Rp. 9.191.000, tgl 30 sebesar Rp. 11.473.000. Pada bulan Mei pada tanggal 7 tercatat sebesar Rp 15.003.500, tgl 14 sebesar Rp 9.410.000, tgl 21 sebesar Rp. 8.907.500, tgl 28 sebesar Rp. 8.905.000. Pada bulan Juni pada tanggal 4 sebesar Rp. 7.863 .000 dan pada tgl 11 sebesar Rp 7.626.500. Jadi jumlah keseluruhan dana infak yang masuk dari mulai januari sampai dengan bulan juni sebesar Rp 210.583.605.

Adapun pengeluaran dana infak pada bulan maret sebesar Rp. 19.930.300, pada bulan April sebesar Rp 30.691.500, pada bulan Mei sebesar Rp. 52.728.000, pada bulan juni sebesar Rp 21.575.000. ${ }^{14}$

\section{KESIMPULAN}

Berdasarkan pembahasan diatas, maka penulis dapat menarik kesimpulan, yaitu:

1. Tata kelola Masjid Agung Nujumul Ittihad Sinjai memperoleh anggaran dana operasional dari jamaah yang tidak bersifat mengikat jumlah maupun waktunya. Anggaran dana operasional diperoleh tidak hanya dari masyarakat setempat tetapi juga masyarakat yang melintas dari daerah lain berinfak. Masjid Agung Nujumul Ittihad setiap malam senin, rabu, kamis, dan minggu melakukan kajian rutin. Masjid Agung Nujumul Ittihad memiliki visi dan misi yang harus diwujudkan bersama para remaja masjid agar tercapai tujuan tertentu.

2. Konsep pengelolaan dana infaq perspektif manajemen dan hukum Islam dapat disimpulkan bahwa pengelolaan dana infak di Masjid Agung Nujumul Ittihad tidak bertentangan dengan Islam karena telah didasari rasa ikhlas maka pengelolaan infak masjid sesuai dengan hukum Islam, dimana pengelolaan dana infak tidak hanya untuk operasional masjid tetapi juga digunakan pendistribusiannya kepada masyarakat

\footnotetext{
${ }^{12}$ Muh Jabir,Perencanaan Dan Pemeliharaan Masjid Nujumul Ittihad Sinjai, Wawancara, Sinja 4 Maret 2021.

${ }^{13}$ Insan, Wakil Bendahara 3 Masjid Agung Nujumul Ittihad Sinjai, Wawancara, 4 Maret 2021.

${ }^{14}$ Supran Bendahara Umum Masjid Nujumul Ittihad Sinjai, Wawancara, Sinjai 12 Maret 2021.
} 
setempat yang berhak untuk menerima infak sesuai aturan agama Islam. Dan manajemen masjid dalam mengembangkan wawasan atau pengetahuan keagamaan jamaah masjid nujumul ittihad yang sangat bermanfaat, dimana dalam manajemen masjid yaitu pemeliharaan masjid, pembentukan remaja masjid, pembentukkan struktur organisasi pengurus masjid, tempat kegiatan sosial dan juga pembukuan keuangan atau laporan keuangan masjid. Penulis menyimpulkan berdasarkan hasil dari wawancara dan laporan keuangan dana infak yang dilaporkan secara transparan setiap hari jumat. 


\section{DAFTAR PUSTAKA}

\section{Buku}

Kompilasi hukum ekonomi Syariah, Jakarta: Kencana Prenada Media Group, 2008.

Mohammad E, dkk" Manajemen Masjid", Jakarta: Gema Insani Press,1996.

\section{Jurnal}

Andi M Fadly Taher. dkk "Sistem Pengelolaan Dana Kotak Infaq dan Sedekah Keliling Masjid di Pasar 45 Manado, Jurnal Ilmiah Al-Syir'ah. Vol.14 No.2, (2016), hal. 54.

Musyfikah Ilyas "Memaknai Fashion dalam Hukum Islam” Al-Daulah: Jurnal Hukum Tata Negara Fakultas Syariah dan Hukum, vol.5, no.1, (Juni 2016), hal. 140.

Al-Qur'an dan Terjemahan (Jakarta: Jatinegara, 2012)

\section{Wawancara}

Wawancara dengan Muhal Arsyad, Dana Dan Keuangan Masjid Nujumul Ittihad Sinjai, 22 Februari 2021.

Wawancara dengan Muh Ramlan Hamid, Ketua Umum Masjid Nujumul Ittihad Sinjai, 26 Februari 2021.

Wawancara dengan Kamaruddin, Petanaman Dan Keindahan Masjid Nujumul Ittihad Sinjai, 26 Februari 2021.

Wawancara dengan Muh Jabir, Perencanaan Dan Pemeliharaan Masjid Nujumul Ittihad Sinjai, 4 Maret 2021.

Wawancara dengan Insan, Wakil Bendahara 3 Masjid Agung Nujumul Ittihad Sinjai, 4 Maret 2021.

Wawancara dengan Supran, Bendahara Umum Masjid Nujumul Ittihad Sinjai, Sinjai 12 Maret 2021. 